\title{
Production and quality of three varieties of chrysanthemum grown in pots with different NPK rates ${ }^{(1)}$
}

\author{
JOICE CRESCENCIO HEIDEMANN(2) * and JOSÉ GERALDO BARBOSA ${ }^{(2)}$
}

\begin{abstract}
Chrysanthemum can be grown for cutting or as a pot plant year-round, providing a constant production flow. In Brazil, little is known about mineral nutrition and fertilization for this crop. Thus, the objective of this work was to evaluate the production and quality of chrysanthemum varieties cultivated in pots with different NPK rates. The experiment was conducted in a completely randomized design with the NPK rates (10-10-10) of $3 \mathrm{~g} \mathrm{~L}^{-1}, 6 \mathrm{~g} \mathrm{~L}^{-1}$ and $9 \mathrm{~g} \mathrm{~L}^{-1}$ and chrysanthemum varieties Sheena, Calabria and Indianapolis. Pots of $1.2 \mathrm{~L}$ capacity were filled with substrate and placed three cuttings per pot kept in a fog chamber under long days. After 21 days, apical pruning was done and started the short-day period. After flowering induction, short days were suspended. It was realized analysis of variance and it was noticed that stem length and EC were affected by NPK rates. It was observed an inverse relation between the increase in NPK rate and cultivation cycle, resulting in precocity of flowering for all varieties. Plants cultivated under $9 \mathrm{~g} \mathrm{~L}^{-1}$ rate did not present toxicity symptoms, suggesting that this dose was more adequate for the production of pot plants for all three varieties.
\end{abstract}

Keywords: Dendranthema grandiflora Tzvelev, floriculture, electrical conductivity, mineral nutrition.

\section{RESUMO}

Produção e qualidade de três variedades de crisântemo em vaso sob diferentes doses de NPK

O crisântemo pode ser cultivado para produção de flores de corte ou como planta para vaso durante o ano todo, proporcionando um fluxo de produção constante. No Brasil, as informações a respeito da nutrição mineral e adubação para a cultura são ainda pouco frequentes. Assim, o objetivo do trabalho foi avaliar a produção e qualidade de plantas de três variedades de crisântemo cultivadas em vaso sob diferentes doses de NPK. O experimento foi conduzido em delineamento inteiramente casualizado com as doses de NPK (10-10-10) $3 \mathrm{~g} \mathrm{~L}^{-1}, 6 \mathrm{~g} \mathrm{~L}^{-1}$ e $9 \mathrm{~g} \mathrm{~L}^{-1}$ e as variedades Sheena, Calabria e Indianapolis. Vasos de 1,2 L foram preenchidos com substrato e utilizadas três estacas por vaso e mantidos em câmara de nebulização sob dias longos (DL). Após 21 dias, foi realizada a poda apical e iniciou-se o fornecimento de dias curtos (DC). Após a indução do florescimento, o DC foi suspenso. Realizouse análise de variância, constatando-se que o comprimento das hastes e a condutividade elétrica foram afetados pelas doses de NPK. Observou-se relação inversa entre aumento da dose de NPK e ciclo de cultivo, resultando na redução do ciclo para as três variedades. As plantas cultivadas sob a dosagem de $9 \mathrm{~g} \mathrm{~L}^{-1}$ não apresentaram sintomas de toxidez, sugerindo que esta dose foi mais adequada para a produção de plantas em vaso de alta qualidade para as três variedades.

Palavras-chave: Dendranthema grandiflora Tzvelev, condutividade elétrica, floricultura, nutrição mineral.

\section{INTRODUCTION}

Commercial floriculture represents one of the most promising segments of contemporary Brazilian agribusiness. In 2016, the sector moved the amount of $\mathrm{R} \$ 6.5$ billion, at the end consumer level, with growth of $6 \%$ over the previous year, sustaining a favorable economic performance, despite the context of economic and financial crisis that affects the country (JUNQUEIRA and PEETZ, 2017).

Chrysanthemum has a prominent place among the most cultivated species in Brazil and in the world due to its beauty, color diversity, durability of inflorescences and for being a relatively easy-to-grow plant. It is sensitive to photoperiod, being classified as a short-day plant, with a 13-hour critical photoperiod (BARBOSA, 2003; FERNANDES et al., 2012; MENEGAES et al., 2017) allowing the control of its flowering. It can be cultivated for cut flower or as pot plant. For potting, there are certain market requirements such as harmony between plant height and pot height and uniform filling.

Substrate temperature, light and fertilization are of paramount importance in quality and productivity of inflorescences (BACKES et al., 2004; PIROLA et al., 2015). The knowledge of nutritional needs of the crop has not only an important impact on quality, productivity and longevity of the inflorescences and plant but also on maximizing the ecosystem efficiency with minimum impact on environment avoiding eutrophication on rivers and lakes (MOTA et al., 2013; SCHWAB et al., 2014).

In Brazil there is little information about fertilization and mineral nutrition for this crop, particularly for potting. Thus, although researches have advanced in recent years, 
many producers still rely on empirical fertilization patterns, resulting in nutrition that is often excessive, causing toxicity and imbalance in plant mineral nutrition (MOTA et al., 2007; BECKMANN-CAVALCANTE et al., 2010; FERNANDES et al., 2012), compromising the production and quality of inflorescences.

Growth conditions found by the plants are not always ideal, mentioning salinity in substrates, often related to fertigation, to the deficiency of a suitable drainage system, and especially to fertilizers in excess. The presence of salts interferes with water potential of the substrate, reducing the potential gradient between substrate solution and the plant, impairing the absorption of water and nutrients (LOPES and MACEDO, 2008), compromising plant quality. The irrigation and fertilization system must be constantly monitored in order to avoid excesses, nutrient wastage or even the plant death due to excessive fertilization, being important the monitoring of the $\mathrm{pH}$ values and electrical conductivity (EC) of the culture environment (SCHAFER and SOUZA, 2005). Thus, the objective of this work was to evaluate growth and development of potted chrysanthemum varieties Sheena, Calabria and Indianapolis with different $\mathrm{N}-\mathrm{P}-\mathrm{K}$ rates, as well as to relate possible symptoms of toxicity with the EC values of the substrates.

\section{MATERIAL AND METHODS}

Experiment was conducted in a greenhouse $\left(20^{\circ} 45^{\prime} \mathrm{S}\right.$ and $42^{\circ} 51^{\prime} \mathrm{W}, 648 \mathrm{~m}$ altitude), from August to November, 2015 .

The completely randomized design (CRD) was used with four rates of NPK fertilizer 10-10-10 (0.0 $\mathrm{g} \mathrm{L}^{-1}, 3.0$ $\mathrm{g} \mathrm{L}^{-1}, 6.0 \mathrm{~g} \mathrm{~L}^{-1}$ and $\left.9.0 \mathrm{~g} \mathrm{~L}^{-1}\right)$ and three replicates, testing on three varieties of chrysanthemum (Sheena, Calabria and Indianapolis) independently. Each experimental unit had a pot $(1.2 \mathrm{~L})$ with three plants.

Substrate consisted of a mixture of soil, sand, manure and commercial substrate in the ratio of $4: 1: 2: 2$, respectively. The final mixture presented $\mathrm{pH} 5.8 ; 0.28 \mathrm{mS}$ $\mathrm{cm}^{-1} \mathrm{EC} ; \mathrm{P}=60.1 \mathrm{mg} \mathrm{dm}{ }^{-3} ; \mathrm{K}=130 \mathrm{mg} \mathrm{dm}^{-3} ; \mathrm{O} . \mathrm{M} .=5.1 \%$; $\mathrm{Ca}=2.9 \mathrm{cmolc} \mathrm{dm}^{-3} ; \mathrm{Mg}=3.1 \mathrm{cmolc} \mathrm{dm}^{-3} ; \mathrm{CTC}=6.44$ cmolc $\mathrm{dm}^{-3}$; and $\mathrm{V}=64 \%$.

Subsequently, fertilization occurred according to the treatments. For each experimental unit, three cuttings coming from chrysanthemum plants of Floriculture Sector were stuck in the substrate and pots were placed in a fog chamber with irrigation frequency of six seconds at every 20 minutes under long days with incandescent bulbs of 60 $\mathrm{W} \mathrm{m} \mathrm{m}^{-2}$ in the period from 10 p.m. to 2 a.m.

At 21 days, after rooting, apical pruning was held leaving two pairs of leaves and pots were transported to a greenhouse, starting the period of short days (SD), covering manually the plants from 5 p.m to 7 a.m using a double-sided cover. SD period stopped from the induction of flowering on, visible by the formation of little buds.

Localized irrigation was performed manually once a day until reaching the field capacity of the pots that was 400 $\mathrm{mL}$. Fertigation was done weekly following CASTRO et al. (2010) methodology. Temperatures inside the greenhouse were an average of $29.4{ }^{\circ} \mathrm{C}$ during the day and $21{ }^{\circ} \mathrm{C}$ during nights with relative humidity of $67 \%$.

When three to five inflorescences per pot were found with at least $50 \%$ of their flowers opened were assessed the following characteristics: flowering cycle - expressed by the number of days from planting to harvest; length of stems (from the bottom of the vase to the last inflorescence); dry matter of leaves, stem and inflorescences per plant (g) determined after $48 \mathrm{~h}$ in a forced air circulation drying oven at $70{ }^{\circ} \mathrm{C}$; number of inflorescences with diameter between 1.0-3.0 $\mathrm{cm}$ and greater than $3 \mathrm{~cm}(\mathrm{~cm})$ - determined with digital caliper; and electrical conductivity of the substrate $\left.(\mathrm{dS} \mathrm{cm})^{-1}\right)$ after harvesting the plants.

Data were submitted to Tukey and regression test with SISVAR software (FERREIRA, 2011).

\section{RESULTS AND DISCUSSION}

\section{Flowering cycle}

In absence of NPK and at the dosages of 3.0 and $6.0 \mathrm{~g} \mathrm{~L}^{-1}$, Sheena was late, with cycle around 98 days. Indianapolis showed intermediate cycles with values about 86 days while Calabria was the most precocious with cycles around 77 days (Figure 1). With increase in NPK rate varieties Sheena and Indianapolis had similar cycles, which were later than variety Calabria. Barbosa et al. (2009) assessing chrysanthemum varieties Dark Flamengo, Calabria and Blush Hawai verified average cycles of 98.1, 93.2 e 92.5 days, respectively. 


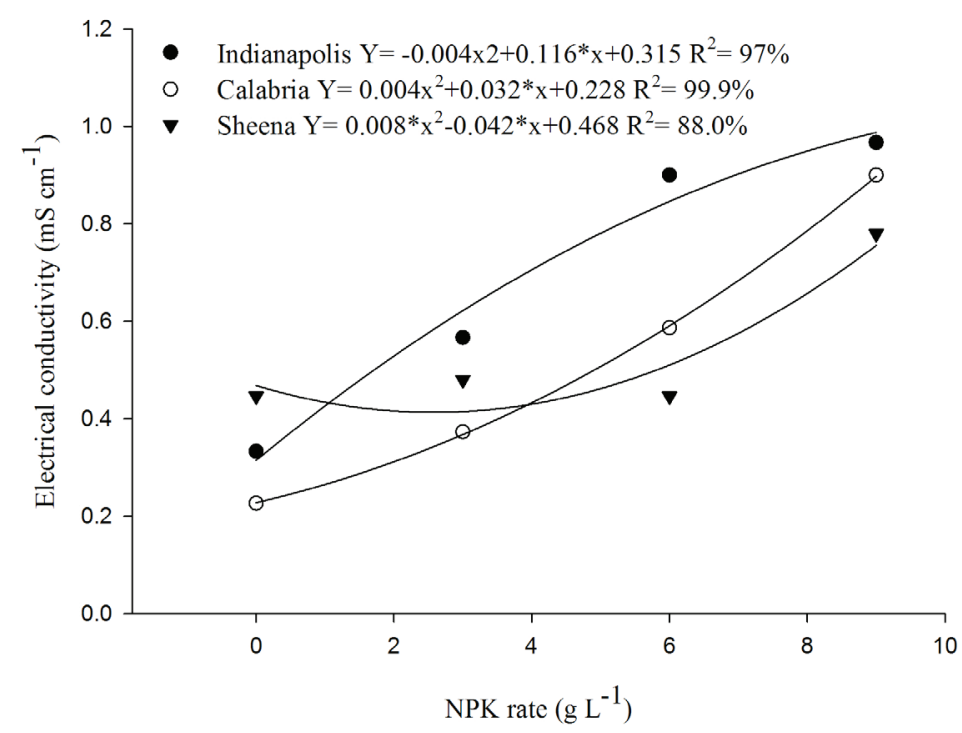

Figure 1. - Regression adjustments for plant cycle in Sheena, Calabria and Indianapolis chrysanthemum varieties, according to NPK rates.

Calabria had the lowest flowering cycle, 75 days, due to the genetic characteristics of the cultivar, which has an early flowering cycle when compared to the others and to the contribution of nitrogen, phosphorus and potassium. Similarly, Indianapolis and Sheena had reductions of approximately 20 and 10 days in their production cycles, respectively, due to fertilization with NPK. These results are due to the fact that plants supply their nutritional needs more efficiently during their growth and developmental stages (BRUM et al., 2007), converging to an earlier flowering, which allows a greater use of the crop structure and at the same time maximizes the producer's financial return.

\section{Dry matter of leaves, stems and length of stems}

For dry matter of leaves was observed that Sheena presented the higher value with $4.15 \mathrm{~g}$ (Table 1). High dry matter value is desirable, since it allows consistent plants with higher photosynthetic rate, contributing to a longer postharvest life (BARBOSA et al., 2005).

Table 1. Average values for dry matter of leaves (DML), dry matter of inflorescences (DMI) and number of inflorescences with diameter between 1-3 cm (N1-3) for Sheena, Calabria, and Indianapolis chrysanthemum varieties.

\begin{tabular}{|c|c|c|c|}
\hline Varieties & DML (g) & DMI (g) & N1-3 \\
\hline Sheena & $2.16 \mathrm{a}$ & $2.33 \mathrm{a}$ & $6.41 \mathrm{a}$ \\
\hline Calabria & $2.94 \mathrm{~b}$ & $2.40 \mathrm{a}$ & $15.91 \mathrm{~b}$ \\
\hline Indianápolis & $4.15 \mathrm{c}$ & $2.78 \mathrm{a}$ & $8.16 \mathrm{a}$ \\
\hline
\end{tabular}

Means followed by the same letter in the column do not significantly differ by the Tukey test at $\mathrm{p}<0.05$.

Length of stems was also affected by NPK rates (Figure 2). Higher values of stem length were observed for Calabria, with average of $19.7 \mathrm{~cm}$, similar to Sheena with $18.6 \mathrm{~cm}$, and higher than variety Indianapolis, with $17.2 \mathrm{~cm}$. Similar results were found by Mota et al. (2007) and Pirola et al. (2015) whom noticed increments in plant height when increasing the dosage of the applied treatment.
This is due to the fact that these nutrients are involved in cell elongation and division, and also because they are fundamental constituents of organelles and compounds involved in photosynthesis, especially nitrogen, thus resulting in response of stem length (BARBOSA et al., 1999; RODRIGUES et al., 2008; CASTRO et al., 2011; BALDOTTO and BALDOTTO, 2015). 


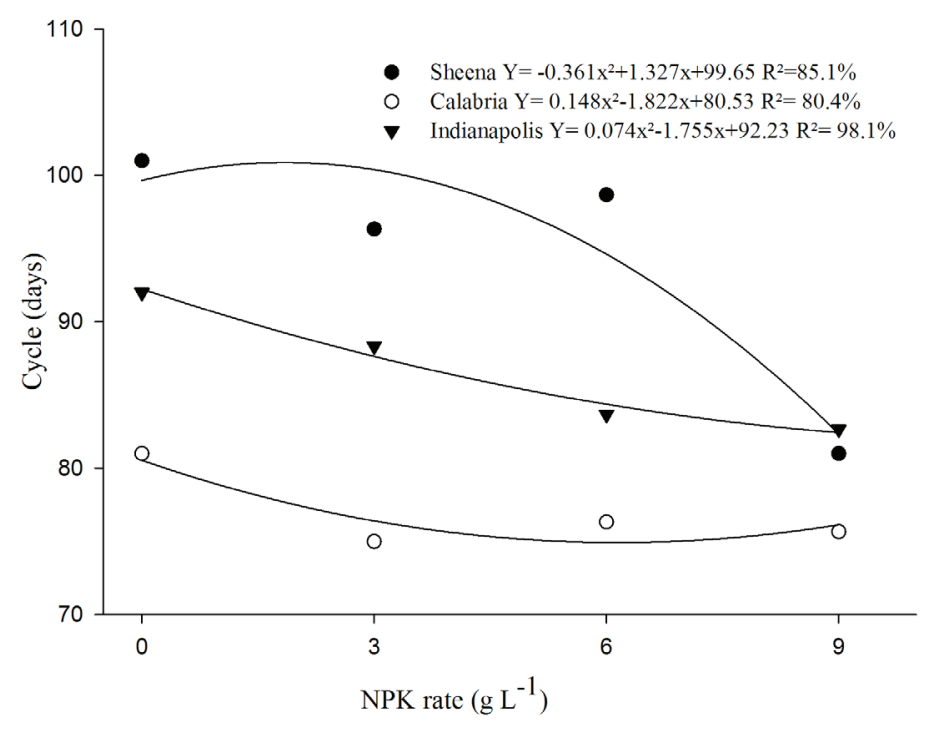

Figure 2. Stem length $(\mathrm{cm})$ as a function of NPK rates applied in cultivation of chrysanthemum plants of Indianapolis, Calabria and Sheena varieties.

According to Veiling Holambra (2006), potted chrysanthemum plants should have a height between 1.5 and 2.5 times the height of the pot in order to fill the pot while also resulting in its harmonic distribution in the pot. Taking into account the height of the pot, $10.0 \mathrm{~cm}$, all varieties and rates of NPK were within the marketing standards for chrysanthemum culture, independently of fertilization, according to standard requirement by the market.

Dry matter and number of inflorescences with diameters between 1-3 and greater than $3 \mathrm{~cm}$

There was no difference for dry matter of inflorescences and number of inflorescences with diameters greater than $3.0 \mathrm{~cm}$, which values were from $2.33 \mathrm{~g}$ for Sheena to 2.78 $\mathrm{g}$ for Indianapolis (Table 1) and from 3.0 to Sheena to 4.3 to Calabria (data not shown), respectively. Yet, taking into consideration number of inflorescences between 1.0$3.0 \mathrm{~cm}$, Calabria indicated means of 15.91 inflorescences (Table 1) being superior to the values found for Sheena and Indianapolis varieties.
Number of inflorescences per pot is considered one of the most important parameters in conformation of the pot, since the higher the number of inflorescences per pot, the better the bouquet formation and, consequently, the better pot quality (GARDE et al., 2013). Other parameters that determine quality of potted chrysanthemum are plant height, plant diameter, and diameter of inflorescences, these characteristics vary according to pot size and the system of conduction and variety (BRUM et al., 2007), as observed in this work.

\section{Electrical conductivity of substrates}

NPK rates affected EC of the substrate showing a positive correlation between NPK rate increase and EC values, as shown in Figure 3. However, these values were not sufficient for causing any sign of toxicity in the plant or reduction on biomass production. Similarly, Mota et al. (2013) and Beckmann-Cavalcante et al. (2010) working with different EC levels and with White Diamond and Miramar varieties did not find any reduction on biomass production rising the concentration of salts in tested treatments. 




Figure 3. Electrical conductivity of the substrate $\left(\mathrm{mS} . \mathrm{cm}^{-1}\right)$ as a function of NPK rates applied in cultivation of chrysanthemum varieties Indianapolis, Calabria and Sheena.

It is of great value to highlight that chrysanthemum is a salinity tolerant plant; whose EC values range from 1.3 to $2.5 \mathrm{mS} \mathrm{cm}^{-1}$. The observed values in this study did not cause symptoms of toxicity in the plants, since most varieties tolerate EC values above $2.5 \mathrm{mS} \mathrm{cm}^{-1}$, as observed by Barbosa et al. (2000) and Barbosa et al. (2015).

\section{CONCLUSIONS}

The $9.0 \mathrm{~g} \mathrm{~L}^{-1}$ NPK rate provided better growth and development of Sheena, Calabria and Indianapolis chrysanthemum varieties in this study. Flowering cycle was reduced as the NPK rate increased, and $3.0 \mathrm{~g} \mathrm{~L}^{-1}$ rate provided a higher precocity for Calabria and $9.0 \mathrm{~g} \mathrm{~L}^{-1}$ rate for Sheena and Indianapolis varieties. None of the varieties showed signs of toxicity due to salinity or excess of nutrients in the substrate.

\section{ACKNOWLEDGEMENTS}

The authors would like to thank the National Council for Scientific and Technological Development (CNPq) and the Department of Plant Science (DFT) of Federal University of Viçosa (UFV).

\section{AUTHORS CONTRIBUTIONS}

JCH: Conducting the experiment and monitoring growth and development of plants; evaluation/data collection; arrangement of experimental data and statistical analysis; bibliographic review and experimental planning; implantation of the experiment according to established treatments; preparation of tables and figures; writing the text. JGB: Bibliographic review and experimental planning; implantation of the experiment according to established treatments; preparation of tables and figures; writing the text.

\section{REFERENCES}

BACKES, F.A.A.L.; BARBOSA, J.G.; BARBOSA, M.S.; MORITA, R.M. Enraizamiento de estacas de crisantemo en espuma fenólica con diferentes concentraciones de solución nutritiva. Floriculura en la Argentina, v.1, n.1, p.23-26, 2004.

BALDOTTO, L.E.B.; BALDOTTO, M.A. Growth and production of ornamental sunflower grown in the field in response to application of humic acids. Ciência Rural, v.45, n.5, p.1000-1005, 2015. DOI: http://dx.doi. org/10.1590/0103-8478cr20140050

BARBOSA, J.G. Crisântemos: Produção de mudas, cultivo para corte de flor, cultivo em vaso, cultivo hidropônico. Viçosa: Aprenda Fácil, 2003. 234p.

BARBOSA, J.G.; BARBOSA, M.S.; MUNIZ, M.A.; ALMEIDA, D.B.; SÁ, P.G., FINGER, F.L.; MARTINEZ, H.E.P.; GROSSI, J.A.S. Production and postharvest quality of chrysanthemum flowers grown in hydroponic system under different N:K ratios. Acta Horticulturae, n.126, p.281-288, 2015. DOI: <10.17660/ ActaHortic.2015.1060.42>

BARBOSA, J.G.; KAMPF, A.N.; MARTINEZ, H.E.P.; KOLLER, O.C.; BOHNEM, H. Chrynthemum cultivation in expanded clay. i. effect of the nitrogen-potassium ratio in the nutrient solution. Journal of Plant Nutrition, v.23, n.9, p.1327-1337, 2000. DOI: <http://dx.doi. org/10.1080/01904160009382103>

BARBOSA, J.G.; MARTINEZ, H.E.P.; KAMPF, A.N. Acúmulo de macronutrientes em plantas de crisântemo sob cultivo hidropônico em argila expandida para florde-corte. Pesquisa Agropecuária Brasileira, v.34, n.4, p.593-601, 1999. 
BARBOSA, J.G.; MUNIZ, M.A.; MARTINEZ, H.E.P.; LEITE, R.A.; CARDOSO, A.A.; BARBOSA, M.S. Concentração de nutrientes em crisântemos de vaso, cultivado sob diferentes relações $\mathrm{NO}^{-3} / \mathrm{NH}^{+4}$. Acta Scientiarum, v.27, n.3, p.387-394, 2005.

BARBOSA, M.S.; BARBOSA, J.G.; MARTINEZ, H.E.P.; GROSSI, J.A.S.; REIS, F.P.; PONTES, T.M. Concentração de nutrientes em crisântemos de corte, cultivados em hidroponia, sob diferentes doses de cálcio. Bioscience Journal, v.25, n.2, p.46-54, 2009.

BECKMANN-CAVALCANTE, M.Z; PIVETTA, K.F.L.; CAVALCANTE, I.H.L.; CAVALCANTE, L.F.; BELLINGIERI, A.; CAMPOS, M.C.C. Condutividade elétrica da solução nutritiva para o cultivo do crisântemo em vaso. Revista Brasileira de Ciência do Solo, v.34, n.1, p.747-756, 2010. DOI: <http://dx.doi.org/10.1590/S010006832010000300016>

BRUM, B.; SANTOS, V.J.; RODRIGUES, M.A.; BELLÉ, R.A.; LOPES, S.J. Crescimento, duração do ciclo e produção de inflorescências de crisântemo multiflora sob diferentes números de despontes e tamanhos de vasos. Ciência Rural, v.37, n.3, p.682-689, 2007. DOI: http:// dx.doi.org/10.1590/S0103-84782007000300013

CASTRO, A.M.C.; SATO, O.; SANTOS, K.H.; ZAPAROLLI, R.A.; SARTORI, S.B.; DEMÉTRIO, G.B. Adubação mineral e orgânica no desenvolvimento de crisântemo. Semina: Ciências Agrárias, v.31, n.1, p.93100,2010 .

CASTRO, A.M.C.; RANDO, E.M.; SANTOS, K.H.; SILDA, D.P.; CHIMBO JUNIOR, A.; BENSI, D.; BRAGA, C.L.; SATO, O.; CARVALHO, F.K. Uso de fontes de nitrogênio visando retardar a senescência em girassol ornamental. Scientia Agrária Paranaensis, v.10, n.1, p. 83-90, 2011. DOI: <http://dx.doi.org/10.1818/sap. v10i1.5286>

FERNANDES, E.P.; REZENDE, C.F.A.; LEANDRO, W.M.;FRAZÃO, J.J.;BARBOSA, J.M. The accumulation of nitrogen, phosphorus and potassium in cut chrysanthemum (Dendranthema grandiflorum) cv. Jospithoven. Semina: Ciências Agrárias, v.33, n.1, p.2939-2948, 2012. DOI: $<10.5433 / 1679-0359.2012$ v33Supl1p2939>

FERREIRA, D.F. Sisvar: a computer statistical analysis system - review. Ciência e Agrotecnologia, Lavras, v. 35, n. 6, p. 1039-1042, 2011.

GARDE, G.P.; MUNIZ, M.A.; PÊGO, R.G.; GROSSI, J.A.S. Data de desponte apical e intensidade luminosa no crescimento e qualidade de crisântemo de vaso. Horticultura Brasileira, v.31, n.1, p.659-663, 2013. DOI: http://dx.doi.org/10.1590/S0102-05362013000400025
JUNQUEIRA, A.H.; PEETZ, M.S. Brazilian consumption of flowers and ornamental plants: habits, practices and trends. Ornamental Horticulture, v.23, n.2, p.178-184, 2017. DOI: http://dx.doi.org/10.14295/oh.v23i2.1070

LOPES, J.C.; MACEDO, C.M.P. Germinação de sementes de couve chinesa sob influência do teor de água, substrato e estresse salino. Revista Brasileira de Sementes, v.30, n.3, p.79-85, 2008.

MENEGAES, J. F.; BACKES, F.A.A.L.; BELLÉ, R.A.; SWAROWSKY, A.; SALAZAR, R.F.S. Avaliação do potencial fitorremediador de crisântemo em solo com excesso de cobre. Ornamental Horticulture, v.23, n.1, p.63-71, 2017. DOI: http://dx.doi.org/10.14295/oh.v23i1.915

MOTA, P.R.D.; FIORIM, A.C.R.; VILLAS BOAS, R.L.; FOLEGATTI, M.V.; LUDWIG, F.; SILVA, M.E.A. Condutividade elétrica da solução nutritiva e acúmulo de macro e micronutrientes no cultivo de crisântemo. Bragantia, v. 72, n.1, p.81-89, 2013. DOI: <http://dx.doi. org/10.1590/S0006-87052013005000015>

MOTA, P.R.D.; VILLAS BOAS, R.L.; SOUSA, V.F.; RIBEIRO, V.Q. Desenvolvimento de plantas de crisântemo cultivadas em vaso em resposta a níveis de condutividade elétrica. Engenharia Agrícola, v.27, n.1, p.164-171, 2007. DOI: http://dx.doi.org/10.1590/S010069162007000100010>

PIROLA, K.; DOTTO, M.; WAGNER JUNIOR, A.; ALEGRETTI, A.L.; CONCEIÇÃO, P.C.; MENDES, A.S. Recipientes e substratos na germinação e desenvolvimento de crisântemo e amor-perfeito. Ornamental Horticulture, v.21, n.2, p.151-160, 2015.

RODRIGUES, T.M.; RODRIGUES, C.R.; PAIVA, R.; FAQUIN, F.; PAIVA, P.D.O.; PAIVA, L.V. Níveis de potássio em fertirrigação interferindo no crescimento/ desenvolvimento e qualidade do crisântemo. Ciência e Agrotecnologia, v.32, n.1, p. 1168-1175, 2008. DOI: < http://dx.doi.org/10.1590/S1413-70542008000400020>

SCHÄFER, G.; SOUZA, P.V.D. Método não destrutivo para monitoramento da reação e salinidade do substrato na produção de mudas cítricas. Laranja, v.26, n.1, p.151-162, 2005.

SCHWAB, N.T.; STRECK, N.A.; REHBEIN, A.; RIBEIRO, B.S.M.R.; ULHMANN, L.O.; LANGNER, J.A.; BECKER, C.C. Dimensões lineares da folha e seu uso na determinação do perfil vertical foliar de gladíolo. Bragantia, v.73, n.2, p.97-105, 2014. DOI: <http://dx.doi. org/10.1590/brag.2014.014>

VEILING HOLAMBRA - Critérios de classificação Veiling Holambra crisântemo de vaso potes 06, 09, 11 e 13. Available in: <http://veiling.com.br/uploads/padrao qualidade/criterios/crisantemo-pt-06-09-11-e-13.pdf> Accessed in: February 02, 2017. 